\title{
Calcium Oxalate Crystal Deposition
}

National Cancer Institute

\section{Source}

National Cancer Institute. Calcium Oxalate Crystal Deposition. NCI Thesaurus. Code C97094.

A finding indicating the formation of calcium oxalate crystal deposits in an organ. 